\title{
Circulating neuroendocrine tumors biomarkers. Why? When? How? Suggestions for clinical practice from guidelines and consensus
}

\author{
Paola Razzore', Giorgio Arnaldi ${ }^{2}$ \\ ${ }^{1}$ SC Endocrinologia, AO Ordine Mauriziano, 10128 Turin, Italy. \\ ${ }^{2}$ Clinica di Endocrinologia e Malattie del Metabolismo, AOU Ospedali Riuniti, 60100 Ancona, Italy.
}

Corresponding Author: Dr. Paola Razzore, SC Endocrinologia, AO Ordine Mauriziano, Largo Turati 62, 10128 Torino, Italy.

E-mail: razzorepaola@hotmail.com

\section{A B S T R A C T}

\begin{abstract}
Neuroendocrine neoplasms (NETs) are rare tumors that are increasing in incidence. NETs are characterized by heterogeneous biological behaviour, clinical presentation and course. A sensitive and specific diagnostic and prognostic circulating biomarker useful for all sites, grading and staging of neuroendocrine tumors is still an unmet need. The aim of this article was to review current neuroendocrine and oncologic scientific society guidelines and position statements, and propose recommendations for the most frequent clinical practice queries on circulating neuroendocrine tumors biomarkers. The authors searched for NCCN, NANETS, ESMO, ENETS, UKINETS, AME management guidelines or position statements available from PubMed up to 7th January 2016. From these results we chose guidelines or position statements published by scientific societies or institutions in USA, Europe and Italy with recognized expertise in neuroendocrine tumor patient management. The authors present suggestions for clinical practice based on this analysis.
\end{abstract}

Key words: Neuroendocrine tumors; neuroendocrine markers; neuroendocrine management; chromogranin A; guidelines; clinical practice

\section{INTRODUCTION}

Neuroendocrine tumors (NETs) are rare but have been increasing in incidence. ${ }^{[1]}$ NETs are characterized by heterogeneous biological behavior, clinical presentation, and course. NETs arise from neuroendocrine cells aggregate in classical endocrine glands -- like adrenal, pituitary and parathyroid -- but also in the diffuse neuroendocrine system (DNES).

An early diagnosis is crucial since lower survival was demonstrated in patients with metastatic disease. ${ }^{[2]}$ However an interval of many years is reported from earliest symptoms to diagnosis. Symptoms are often nonspecific and do not lend themselves to identifying the specific underlying tumor. In addition, clinical presentations are protean and mimic a variety of other non-neoplastic diseases. ${ }^{[3]}$ Many specialists may be individually involved from earliest signs and symptoms but a multidisciplinary team may be the most successsful approach to reduce time latency from symptoms to diagnosis and improve overall survival. ${ }^{[4]}$ In this context the choice of circulating neuroendocrine biomarkers and interpretation of these

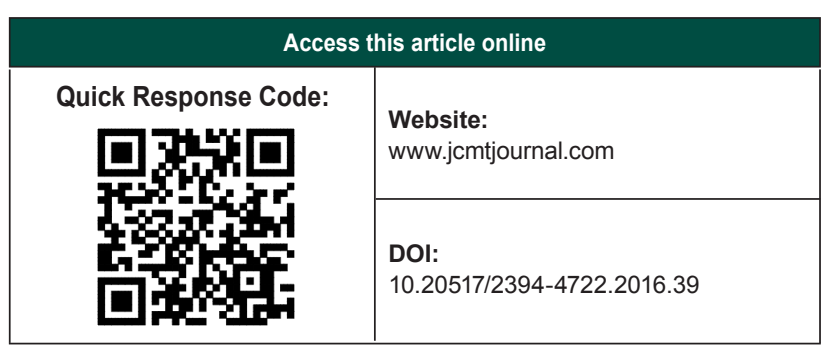

values needs to be carefully considered with respect to the clinical presentation and other putative diagnoses. ${ }^{[5,6]}$ Many different diagnostic and therapeutic approaches are reported in real life NET manage-ment according to different physician expertise, accessibility of medical care in different countries, and financial reimbursement. Translation of guidelines and consensus into clinical practice is often difficult because suggestions are not always universally applicable.

The aim of our paper was to review current neuroendocrine and oncologic scientific society guidelines and position statements and provide recommendations for the most frequent clinical practice queries on circulating neuroendocrine tumor biomarkers.

We searched the National Comprehensive Cancer Network $(\mathrm{NCCN})$, North American Neuroendocrine Tumor (NANETS), European Society of Medical Oncology (ESMO), European Neuroendocrine Tumor Society

This is an open access article distributed under the terms of the Creative Commons Attribution-NonCommercial-ShareAlike 3.0 License, which allows others to remix, tweak, and build upon the work non-commercially, as long as the author is credited and the new creations are licensed under the identical terms.

For reprints contact: service@oaepublish.com

How to cite this article: Razzore P, Arnaldi G. Circulating neuroendocrine tumors biomarkers. Why? When? How? Suggestions for clinical practice from guidelines and consensus. J Cancer Metasta Treat 2016;2:348-56.

Received: 08-02-2016; Accepted: 18-07-2016 
(ENETS), UK and Ireland Neuroendocrine Tumour Society (UKINETS) and Associazione Medici Endocrinologi (AME) for neuroendocrine tumor management guidelines or position statements using PubMed source. We terminated our search including results on 7th January 2016. From the PubMed results, we chose guidelines or position statements published by scientific societies or institutions in USA, Europe and Italy with recognized exper-tise in neuroendocrine tumor patient management. We present suggestions for clinical practice based on this analysis.

\section{WHY SHOULD CIRCULATING NEUROENDOCRINE BIOMARKERS BE USED?}

The current view of DNES was descending from Feyrter's 1938 initial discovery of neurons and endocrine cells sharing a common phenotypic program. These cells were characterized by the expression of markers such as neuropeptides, chromogranins, neuropeptide processing enzymes subtilase-like pro-protein convertases (SPC2 and SPC3) or dense core secretory granules. ${ }^{[7]}$ All of these cells can secrete products such as peptides and biogenic amines that are tumour specific and may serve as markers for the diagnosis and follow-up of treatment. ${ }^{[8]}$ In a few cases, clinical presentation is related to a single hormonal secretion as in insulinoma and gastrinoma, carcinoid syndrome or pheochromocytoma but more frequently the diagnosis is incidental or as a result of tumor bulk. ${ }^{[9]}$ Circulating tumor biomarkers are readily available and should be implemented in clinical practice to diagnose and monitor patients with NETs. In fact, seventeen different circulating biomarkers have been identified for gastroenteric neuroendocrine tumors and more than 30 gut peptide hormone genes are known, which express

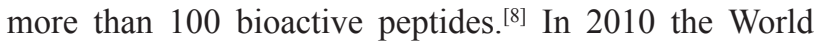
Health Organization published the new neuroendocrine tumors classification ${ }^{[10]}$ and now there is consensus on routinely chromogranin $\mathrm{A}(\mathrm{CgA})$ and synaptophysin immunohistochemical assessment for neuroendocrine diagnosis. ${ }^{[11]}$ On the other hand, the use of a single monoanalytical circulating biomarker for neuroendocrine tumors management - although frequently recommended - is now controversial ${ }^{[12]}$ but, so far, unavoidable in NET management while waiting for new promising circulating biomarkers to be validated in the future.

\section{WHICH CIRCULATING BIOMARKERS HAVE A ROLE IN NEUROENDOCRINE TUMOR MANAGEMENT?}

The cytoplasm of neuroendocrine cells is occupied by a large number of secretory granules of varying electron densities, size and shape, and is the storage site of secretory products [i.e. serotonin, 5-hydroxytryptamine (5-HT), tachykinins and gastrin]. Upon specific stimulation, granules are translocated to the cell membrane and their content released by exocytosis. Granins are found as major, or principal, components of the soluble core of densecore secretory granules in neuroendocrine cells and are secreted in a physiologically regulated manner. There are 8 members in granin family and $\mathrm{CgA}$ and chromogranin $\mathrm{B}(\mathrm{CgB})$ are the most clinically interesting. ${ }^{[8]}$ However, the precise function of individual granins is dependent on the presence of other granins and hormones produced by a specific neuroendocrine cell, the presence of proteolytic processing enzyme and their inhibitors and activators, as well as the density and localization of calcium pumps and exchangers. ${ }^{[13]}$ Tumors of neuroendocrine origin usually present with increased plasma levels of serum or plasma $\mathrm{CgA}^{[8]}$ but the sensitivity of $\mathrm{CgA}$ measurements in patient with NETs is only about $60-90 \%$ with a specificity of less than $50 \%$ due to concomitant therapy with protonpump inhibitors (PPIs) or intercurring oncological or non-oncological diseases. ${ }^{[14,15]}$ However a recent metaanalysis demonstrated that abnormally high circulating $\mathrm{CgA}$ levels are a characteristic feature of patients with NETs and could serve as non-invasive diagnostic markers of NETs in clinical practice. ${ }^{[16]} \mathrm{CgA}$ is considered a pan-neuroendocrine marker and notably highest concentrations were found in midgut NETs especially with liver metastasis. ${ }^{[17-19]}$ Pancreastin is a post-translational processing product of $\mathrm{CgA}$ and was proposed as useful diagnostic marker because more standardized assays and lower PPIs exposure interferences than $\mathrm{CgA}$ are reported. A predictive and prognostic value was also demonstrated because pre- and post-surgical levels might better reflect neuroendocrine disease burden and outcome. ${ }^{[20]}$ Other monoanalyte general neuroendocrine biomarkers used in managing NETs such as $\mathrm{CgB}$, the cytoplasmatic glycolytic enzyme named neuron-specific enolase (NSE), and pancreatic polypeptide (PP) have been used with highest levels in small-cell lung cancer, poorly differentiated tumors and non-functioning pancreatic tumors, respectively, with low diagnostic performance. Also for $\mathrm{CgB}$ and NSE, sensitivity and specificity performances were reported inadequate for diagnosis and prognostic universal use ${ }^{[12]}$ according to the National Institutes of Health (NIH) biomarker classification system criteria. ${ }^{[1]}$

Gastrin is a diagnostic marker for Zollinger Ellison syndrome characterized by recurrent peptic ulcers and secretory diarrhea. Gastrin levels higher than 10 fold upper limit of normal in the setting of high gastric acid output is suggestive of gastrinoma. Determination of gastrin levels after a secretin test increases sensitivity in case of borderline levels. ${ }^{[22]}$ Insulin is a specific marker of insulinoma and biochemical diagnosis depends on inappropriate insulin levels during a fasting glucose tolerance test. ${ }^{[23]}$

Neuroendocrine tumors may secrete urinary 5-hydroxyindoleacetic acid (u-5HIAA), a metabolite of 5-HT but also vasoactive intestinal peptide (VIP), glucagon and somatostatin with specific syndromes such as carcinoid syndrome, watery diarrhea, sweet syndrome or association of gallstones, diabetes and steatorrhea. Even 
more rarely, tumors can secrete corticotropn releasing factor (CRF) and/or adrenocorticotropic hormone (ACTH), growth hormone releasing hormone (GHRH), arginine vasopressine (AVP), parathyroid-hormone related peptide (PTH-rp) or calcitonin with paraneoplastic Cushing's disease, acromegaly, inappropriate antidiuretic hormone secretion syndrome (SIADH).

Calcitonin is a peptide hormone that is normally secreted by thyroid $\mathrm{C}$ cells, but may be rarely produced ectopically by neuroendocrine tumors especially pancreatic NETs usually in association with other ectopically produced peptides and frequently with $\mathrm{AVP}^{[24]}$ along with typical clinical symptoms of diarrhea and electrolyte disturbance.

Secretion of luteinizing hormone releasing hormone (LHRH), erythropoietin, cholecystokinin (CCK), renin and glucagon-like peptide 1 (GLP-1) in NETs are presented in only a few case reports or miniseries papers. ${ }^{[25]}$ Diagnosis of these tumor subtypes is sometimes very difficult and so a multidisciplinary neuroendocrine team trained to suspect the disease based on symptoms is very important for early diagnosis. ${ }^{[6]}$ For those paraneoplastic syndromes, the circulating biomarkers are not the starting point but the conclusion of a very difficult pathway from subtle and misleading clinical manifestation and biochemical alteration to diagnosis. For example potassium levels and euvolemic hyponatremia are 'per se' markers of possible ectopic Cushing disease or SIAD when presenting in a particular clinical context. ${ }^{[26,27]}$

During the natural course of disease, additional peptides could be secreted or co-secreted ${ }^{[28]}$ resulting in different overlapping clinical manifestations with potential impacts on morbidity and mortality. These possibilities further complicate the puzzle that is NET patient management.

\section{ARE CIRCULATING BIOMARKERS USEFUL IN THE DIFFERENTIATION BETWEEN FUNCTIONAL AND NON- FUNCTIONAL TUMOURS?}

The spectrum of clinical presentation of NETs is highly variable. Many are incidental findings, whereas other patients present with mass effects of the primary tumour or metastases (usually liver). Most NETs are nonfunctional or secrete peptides with low biological consequences. Approximately $10-20 \%$ of NETs are functional and present with an associated endocrine syndrome. They include tumors that secrete insulin (insulinoma) and gastrin (gastrinoma) but more rarely also vasointestinal peptide (VIPoma), glucagon (glucagonoma), somatostatin (somatostatinoma), antidiuretic hormone (tumor responsible of SIAD) adrenocorticotropic hormone (ectopic ACTHoma), growth-hormone releasing hormone (ectopic GHRHoma), calcitonin (medullary thyroid carcinoma), parathyroid hormone (ectopic secretion of PTH), vasoactive compounds, including biogenic amines (tumor responsible of carcinoid syndrome) and catecholamines (pheochromocytoma). In these cases, a range of specific peptide hormones may also be measured and are useful as diagnostic and prognostic biomarkers. Both functional and nonfunctional NETs produce $\mathrm{CgA}$ but this marker does not distinguish between functional and nonfunctional tumors. ${ }^{[2]}$

\section{WHEN SHOULD BIOMARKERS TESTING BE PERFORMED?}

Nonspecific circulating NET biomarkers do not have a crucial role in NET diagnosis and are not recommended for population screening in the absence of strong clinical or radiological evidence of tumor presence. ${ }^{[5,6]}$

$\mathrm{CgA}$ is correlated with tumor load and levels tend to be highest in metastatic cancer, particularly in the liver. ${ }^{[17]}$ Recently however a meta-analysis reported a sensibility and specificity of $73 \%$ and $95 \%$ respectively for $\mathrm{CgA}$ with higher diagnostic accuracy. ${ }^{[16]}$ u-5HIAA is mandatory in patients with carcinoid syndrome but not as useful in patients with foregut (bronchial, gastric) or hindgut (rectal) NETs or in most patients with pancreatic NETS which do not secrete serotonin. ${ }^{[29]}$ Its value is dependent on tumor load and only very highly levels $(>5,000 \mu \mathrm{g} / \mathrm{L})$ have been demonstrated to have a prognostic role in metastatic disease. ${ }^{[19-30]}$ There is consensus about weak diagnostic role for $\mathrm{CgA}$ and u-5HIAA in early tumor detection for non-functioning tumors. ${ }^{[5,29,31-33]}$

The significance of NSE is limited in guidelines to poorly differentiated tumors but recent reports pointed to a possible prognostic role for this marker on progressionfree survival, overall survival, as a marker of treatment outcome in well differentiated, advanced pancreatic neuroendocrine tumors (pNET) during everolimus treatment ${ }^{[34]}$ and more recently as a prognostic marker in gastroenteroNETs. ${ }^{[35]}$ For syndromic patients the biomarkers should be evaluated according to signs and symptoms from the first diagnostic step. ${ }^{[29]}$

In 2011, the NET Task Force of the National Cancer Institute GI Steering Committee recommended the inclusion of serial plasma $\mathrm{CgA}$ measurements into all prospective trials for validation as a prognostic and potential biomarker predicting response. ${ }^{[32]}$ All guidelines recommend $\mathrm{CgA}$ in all NETs at diagnosis and during follow up as well as u-5HIAA for carcinoid tumors and specific markers according to clinical syndrome in functioning tumors. [Table 1]

\section{DO CIRCULATING BIOMARKERS CORRELATE WITH TUMOR BURDEN?}


Table 1: Comparative practical clinical suggestion for circulating NET biomarkers use in functioning and nonfunctioning tumors from NCCN 2.2015, NANETS 2010-2013, ESMO 2012, ENETS 2009-2015-2016, UKINETS 2012 guidelines and AME posizione statement 2014

\begin{tabular}{|c|c|c|c|c|c|}
\hline $\begin{array}{l}\text { Source of } \\
\text { indications }\end{array}$ & Cromogranin A & NSE & u-5HIAA & $\begin{array}{l}\text { Plasma gastrin, } \\
\text { insulin, } \\
\text { glucagon, } \\
\text { somatostatin, } \\
\text { VIP, PP }\end{array}$ & $\begin{array}{c}\text { Others } \\
\text { (plasma } \\
\text { calcitonin, GHRH, } \\
\text { IGF1, ACTH, } \\
\text { PTH-rp)* }\end{array}$ \\
\hline $\begin{array}{l}\text { NCCN } \\
2.2015^{\mid 32]}\end{array}$ & $\begin{array}{l}\text { YES for NENs diagnosis } \\
\text { and FU }\end{array}$ & & $\begin{array}{l}\text { YES for diagnosis } \\
\text { and FU }\end{array}$ & $\begin{array}{l}\text { YES* for diagnosis } \\
\text { and FU } \\
\text { YES PP in pNEN } \\
\text { for diagnosis and FU }\end{array}$ & $\begin{array}{l}\text { YES* for diagnosis } \\
\text { and FU }\end{array}$ \\
\hline $\begin{array}{l}\text { NANENS } \\
\text { 2010-2013 }^{[29,37-40]}\end{array}$ & $\begin{array}{l}\text { YES GEP-NENs } \\
\text { diagnosis and FU } \\
\text { (only if + at diagnosis } \\
\text { and not resected) } \\
\text { SUGGESTED } \\
\text { THY-BRO NENs } \\
\text { diagnosis and FU }\end{array}$ & $\begin{array}{l}\text { Useful in THY- } \\
\text { BRO diagnosis } \\
\text { and FU }\end{array}$ & $\begin{array}{c}\text { YES diagnosis } \\
\text { and FU mid-gut } \\
\text { NENs } \\
\text { YES* others NENs }\end{array}$ & $\begin{array}{l}\text { SUGGESTED** } \\
\text { for diagnosis and FU } \\
\text { (only if significant } \\
\text { before) }\end{array}$ & $\begin{array}{l}\text { SUGGESTED** } \\
\text { for diagnosis and FU } \\
\text { (only if significant } \\
\text { before) }\end{array}$ \\
\hline $\begin{array}{l}\text { ESMO } \\
2012^{[41-42]}\end{array}$ & $\begin{array}{l}\text { YES GEP NEN diagnosis } \\
\text { and FU } \\
\text { YES THY-BRO diagnosis } \\
\text { and FU }\end{array}$ & YES in THY-BRO & $\begin{array}{l}\text { YES in SI-NEN } \\
\text { YES* in } \\
\text { THY-BRO }\end{array}$ & $\begin{array}{l}\text { YES* for diagnosis } \\
\text { and FU } \\
\text { NF-pNEN USEFUL } \\
\text { PP }\end{array}$ & $\begin{array}{l}\text { YES* in THY-BRO } \\
\text { (ACTH-GHRH- } \\
\text { IGF1) }\end{array}$ \\
\hline $\begin{array}{l}\text { ENETS } \\
\text { 2015-2016 } \\
{[11,22,25,31,43,44]}\end{array}$ & $\begin{array}{l}\text { YES GEP-NEN diagnosis } \\
\text { and FU } \\
\text { USEFUL in NEC } \\
\text { diagnosis and FU } \\
\text { YES THY-BRO diagnosis } \\
\text { and FU }\end{array}$ & $\begin{array}{c}\text { Useful in NEC } \\
\text { diagnosis and FU }\end{array}$ & $\begin{array}{c}\text { YES in SI-NEN } \\
\text { YES* in THY-BRO }\end{array}$ & $\begin{array}{l}\text { YES* for diagnosis } \\
\text { and FU }\end{array}$ & $\begin{array}{l}\text { YES* for diagnosis } \\
\text { and FU }\end{array}$ \\
\hline $\begin{array}{l}\text { UKINETS } \\
\text { 2012 }^{\mid 33]}\end{array}$ & $\begin{array}{l}\text { YES for NENs diagnosis } \\
\text { and FU }\end{array}$ & & $\begin{array}{l}\text { YES in SI, digiunal, } \\
\text { colon, appendiceal } \\
\text { NENs }\end{array}$ & $\begin{array}{l}\text { YES* for diagnosis } \\
\text { and FU } \\
\text { NF-pNEN USEFUL } \\
\text { PP }\end{array}$ & $\begin{array}{l}\text { YES* for diagnosis } \\
\text { and FU }\end{array}$ \\
\hline $\begin{array}{l}\text { AME } \\
2014^{[5]}\end{array}$ & $\begin{array}{c}\text { YES for GEP-NEN } \\
\text { diagnosis and follow only } \\
\text { after diagnosis or strong } \\
\text { clinical suspicion }\end{array}$ & & $\begin{array}{l}\text { YES* diagnosis } \\
\text { YES for FU } \\
\text { if significant before }\end{array}$ & $\begin{array}{c}\text { YES* } \\
\text { NOT PP } \\
\text { in pratical clinical use }\end{array}$ & YES* \\
\hline
\end{tabular}

NCCN: National Comprehensive Cancer Network; NANETS: North American Neuroendocrine Tumor; ESMO: European Society of Medical Oncology; ENETS: European Neuroendocrine Tumor Society; UKI NETS: UK and Ireland Neuroendocrine Tumour Society; NSE: plasmatic neuron-specific enolase; u-5HIAA: urinary 5-Hydroxy-indolacetic acid; NENs: neuroendocrine tumors; VIP: vasoactive ntestinal peptide; PP: pancreatic polypeptide; GHRH: growth hormone releasing hormone; IGF1: insulin like growth factor 1; ACTH: adrenocorticotropin; PTH-rp: parathyroid-hormone like hormone; YES: recommended; FU: follow up; YES*: recommended when clinically indicated; THY-BRO: neuroendocrine thymic and bronchial tumors; GEP-NEN: neuroendocrine gastroenteric tumors; SUGGESTED**: suggested a large panel of markers at diagnosis or key point individually tailored; NEC: neuroendocrine carcinoma; SI-NEN: small intestine neuroendocrine tumors; NF-pNENs: non functioning pancreatic neuroendocrine tumors; NOT: recommend against

relationship between biomarker level and the degree of disease burden, higher levels are frequent in patients with metastasis, particularly in the liver. In other words, circulating biomarkers may reflect the tumor burden. Circulating markers are useful for monitoring specific tumors by providing a surrogate endpoint: $\mathrm{CgA}$ for the majority of cases, pancreastatin for hepatic tumor load, and neurokinin A for serotonin-secreting tumors of the small bowel. ${ }^{[33]}$ In particular, circulating $\mathrm{CgA}$ is higher in patients with large metastases compared with localized disease or even limited hepatic involvement (when assessed as $<25 \%, 25-50 \%,>50 \%$ ) and correlates with survival. In addition, $\mathrm{CgA}$ levels are reduced after hepatic resection or transplantation. In a retrospective study, a CgA decrease of $80 \%$ or more was predictive of complete symptom resolution and disease stabilization. By contrast, reduction of urinary 5-hydroxyindoleacetic acid concentrations of $80 \%$ or more (or normalization) was predictive of symptomatic relief but not of disease stabilization. ${ }^{[45]}$

Despite the fact that gastrinomas show high circulating 
Table 2: Pitfalls and bottlenecks and possible remedies for circulating chromogranin A and gastrin interpretation

$\begin{array}{lll}\begin{array}{l}\text { Pitfalls and } \\ \text { bottleneck }\end{array} & \text { Possible causes } & \text { Remidies suggested }\end{array}$

High CrA levels

during diagnostic

work up for NETs
Others disease

and cancers

than NETs

Doubtful in accuracy determination

High individual intervariability

$$
\text { Drugs }
$$

Unexpected individual changes in patient with known NETs

High gastrin levels in patient with clinical suspicion of gastrinoma

\section{Doubtful in accuracy} determination

High individual intervariability

Different assay and normal values in different labs

Samples from different physiological condition

Consider drugs interference (SSA)

Drugs interference (PPIs) Keep in mind non-malignant pathological causes of elevated CrA as severe hypertension, systemic inflammatory response syndrome, pulmonary obstructive disease, bowel disease renal insufficiency, liver or heart failure, chronic gastritis, chronic hepatitis, pancreatitis, Helicobacter Pylori infection, inflammatory bowel disease, hyperthyroidism, giant cell arthritis, systemic lupus erythematosous, exercise-induced physical stress

Keep in mind malignant pathological causes of elevated CrA others than NETs as breast cancer, hepatocellular carcinoma, pancreatic adenocarcinoma, colon cancer, ovarian cancer, prostate cancer, medullary thyroid cancer

Recommend only certificated laboratories with high quality control certification

Complete with imaging according to clinical presentation

Repeat determination if doubtful

Stop proton pump inhibitor 2 weeks before or according with drugs half life

Recommend only certificated laboratories with high quality control certification and the same laboratory and assay for each patient

Report information on lab and normal reference in patient medical record

Check for possible new drugs or physiological interference (fasting, exercise etc.)

Recommend CrA determination during long acting SSA therapy at regular interval after drug injection

If crucial data for diagnosis or therapy management retest in same condition Compare biochemical, clinical and imaging data

Stop PPIs under careful patient monitoring (in-patient setting or daily checks) and switch to $\mathrm{H} 2$ receptor antagonist

If PPIs interruption is not clinically indicated try to tapered the IPPs dose

If the diagnosis is unclear (fasting serum gastrin $<10 \times$ increased, gastric $\mathrm{pH}<2$, no tumor imaged), a secretin test is indicated

Concomitant disease interference

Consider atrophic gastric, Helicobacter Pylori infection, renal failure, short bowel syndrome

NETs: neuroendocrine tumors; PPIs: proton pump inhibitors; SSA: somatostatin analogues

CgA values even in the absence of liver metastasis, gastrin levels are generally proportional to tumor burden and highest gastrin levels are present in patients with metastatic disease. In addition, gastrin seems higher in pancreatic compared to duodenal primary tumors, with no discernible difference between sporadic and multiple endocrine neoplasia (MEN1) or Zollinger Ellison syndrome patients. ${ }^{[46]}$ On the contrary, authors of a recent consensus agreed that circulating biomarkers levels in patients with neuroendocrine tumors do not correlate with tumor grade and do not differentiate low-level malignancy from high-grade disease. ${ }^{[12]}$

\section{SHOULD CIRCULATING BIOMARKERS BE USED IN DISEASE FOLLOW UP?}

When specific circulating biomarkers are elevated at the diagnosis in a patient there is indication to follow these over time. If new signs and symptoms emerge, it is necessary to test for new paraneoplastic syndromes according to clinical presentation. ${ }^{[6]}$

All guidelines [Table 1] recommend the use of CgA for follow up in all NETs even though there is an absence of prospective studies supporting its use. 


\section{SHOULD BIOMARKERS REFLECT INTERVENTION?}

$\mathrm{CgA}$ has been used in gastroenteric NETs as a predictive biomarker to identify patients most likely to have durable responses to long acting somatostatin analogue therapy. ${ }^{[4]}$ Further, early decreases in $\mathrm{CgA}$ after somatostatin analogues plus everolimus was predictive of early response in pNET patients. ${ }^{\left[{ }^{[3]}\right.}$ Increases in CgA levels after radical surgery in a large Italian observational study was reported to be predictive of tumor relapse 9-12 months before the clinical and radiological evidence of disease recurrence. ${ }^{[48]}$ In a recent paper, $\mathrm{CgA}$ was an early predictor of recurrence 6 months before radiological progression in metastatic NETs. ${ }^{[49]}$ A reduction of $>80 \%$ in $\mathrm{CgA}$ after cytoreductive surgery was shown to predict disease control[50] and reduction of $\mathrm{CgA}$ was observed after successful peptide receptor radionuclide therapy ${ }^{[51]}$ and liver transplantation. ${ }^{[52]}$

Table 3: Pitfalls and bottlenecks and possible remedies for circulating u-5HIAA

\begin{tabular}{|c|c|}
\hline $\begin{array}{l}\text { Pitfalls and } \\
\text { bottleneck }\end{array}$ & Possible causes \\
\hline \multirow{6}{*}{$\begin{array}{l}\text { High u-5HIAA } \\
\text { in patient with } \\
\text { suspected or } \\
\text { known NETs }\end{array}$} & $\begin{array}{l}\text { Urinary collection } \\
\text { not correct }\end{array}$ \\
\hline & $\begin{array}{l}\text { Intraindividual } \\
\text { Variation }\end{array}$ \\
\hline & $\begin{array}{l}\text { Doubtful in accuracy } \\
\text { determination }\end{array}$ \\
\hline & Others disease \\
\hline & $\begin{array}{l}\text { Tryptophan/ } \\
\text { serotonin-riche food } \\
\text { consumption }\end{array}$ \\
\hline & Drugs interference \\
\hline \multirow[t]{5}{*}{$\begin{array}{l}\text { Low u-5HIAA } \\
\text { in patients with } \\
\text { known or highly } \\
\text { suspected NETs }\end{array}$} & $\begin{array}{l}\text { Urinary collection } \\
\text { not correct } \\
\text { Intraindividual } \\
\text { variation }\end{array}$ \\
\hline & $\begin{array}{l}\text { Doubtful in } \\
\text { accuracy } \\
\text { determination }\end{array}$ \\
\hline & Drugs interference \\
\hline & Alcohol addiction \\
\hline & $\begin{array}{l}\text { Possible inhibitory } \\
\text { roles of SSA }\end{array}$ \\
\hline
\end{tabular}

Give some written information how to collect $24 \mathrm{~h}$ urine and to conserve. If result is doubtful and crucial for diagnostic and therapeutic choose repeat

Perform two consecutive 24-h urine collections and take mean value of these two especially when collection required for diagnosis or when crucial for terapeutic choose Recommend only certificated laboratories with high quality control certification

Keep in mind others pathological causes of elevated u-5HIAA as coeliac and Whipple's disease, intestinal stasis and cystic fibrosis

Exclude from the diet from $72 \mathrm{~h}$ preceding and during urine collection plums, pineapples, bananas, eggplants, tomatoes, avocados, walnuts, avocados, kiwi, pecans, coffee, tea, cocoa, chocolate, vanilla, sweets and cookies

Keep in mind possible drugs interference. Stop if not contraindicated. u-5HIAA levels were increased during Acetaminophene, naproxen, coumaric acid, phenacetin, diazepam, ephedrine, glyceryl guaiacolate, methocarbamol, reserpine, cisplatin, fluorouracil, melphalan, rauwolfia

Give some written instruction on drugs and food restriction and report all drugs in medical records

The same as for high levels

Keep in mind possible drugs interference. Stop if not contraindicated. U-5HIAA levels were reduced during Chlorpromazine, heparin, imipramine, isoniazid, levodopa, monoamine oxidase inhibitors, methenamine, methyldopa, phenothiazines, promethazine, tricyclic antidepressants, chlorophenylalanine, corticotrophin, guanfacine, imipramine, isocarboxazid, isoniazid, levodopa, MAO inhibitors, moclobemide, acetylsalicylic acid, streptozotocina uses

Ethanol reduce $\mathrm{u}-5 \mathrm{HIAA}$

SSA is known to decrease u-5HIAA. Assays for diagnostic purposes should be made in patients not on somatostatin analogues therapy

In the follow up setting urinary samples need to be collected on stable or comparable SSA doses

Report in patient medical record type of somatostatin analogue and frequency of administration and eventually subcutaneous octreotide performed in the last $24 \mathrm{~h}$ before determination

NETs: neuroendocrine tumors; PPIs: proton pump inhibitors; SSA: somatostatin analogues; u-5HIAA: urinary 5-Hydroxy-indolacetic acid 


\section{HOW TO AVOID MISINTERPRETATION OF CGA, GASTRIN AND U-5HIAA IN CLINICAL PRACTICE?}

There are many conditions that interfere with $\mathrm{CgA}$ and $\mathrm{u}$-5HIAA measurements. For $\mathrm{CgA}$ there is no universally accepted $\mathrm{CgA}$ assay and the different methodologies can lead to confusing results. Many physiological conditions as stress, pregnancy or exercise can increase circulating $\mathrm{CgA}$ levels and the same is true for many drugs and nonneuroendocrine diseases. U-5HIAA measurements also have inherent pitfalls since they require a $24 \mathrm{~h}$ urine collection and are subject to interference by dietary habits. ${ }^{[2,5,8,9,13-15,29,31,33]}$ Tables 2 and 3 show the most important pitfalls and bottlenecks and possible remedies in $\mathrm{CgA}$, gastrin and $\mathrm{u}-5 \mathrm{HIAA}$ interpretation and provide suggestions to reduce interference in circulating biomarker measurements for more accurate tumor management.

\section{MONOANALYTE OR MULTIANALYTES?}

The identification of effective biomarkers in patients with NETs is a high priority. In a recent Delphi consensus, the panel of neuroendocrine experts agreed that an acceptable standard for a diagnostic biomarker should have a sensitivity of at least $80 \%$, specificity of at least $90 \%$, and positive and negative predictive values of each at $80 \%$ or more. ${ }^{[12]}$ In addition, the biomarker should be able to provide information regarding the proliferative and metastatic capacity of a tumor, the identification of surgical and medical treatment effectiveness and correlate with patient survival. Unfortunately current universal circulating biomarkers are not able to provide this standard and, in particular, the role of $\mathrm{CgA}$ in the diagnosis of neuroendocrine tumors is decreasing.

The principal limitation in the measurement of circulating $\mathrm{CgA}$ is the absence of a gold standard assay and wide variability of results from different kits and laboratories. In addition, false positive results are reported as a result of other neoplasia (prostate and breast cancer and hepatocellular carcinoma) and common conditions (kidney, liver or heart failure, chronic gastritis, inflammatory bowel disease, PPI use, essential hypertension and physical stress). In addition, the current biomarkers used for gastroenteropancreatic NETs are inadequate for bronchopulmonary NETs and vice versa. For these reasons, a multianalyte approach would likely be more effective compared to a monoanalyte circulating biomarker. To this end, a specific multianalyte assay with algorithmic analyses (MAAA) named NETest has recently been developed. NETest is a PCR-based, 51-transcript signature that is based on correlating and normalizing multiple sets of variables that represent gene clusters specific to NETs and their biological behavior. The use of this blood-based test is proposed to facilitate early detection of disease recurrence and to predict therapeutic efficacy. The diagnostic performance of MAAAs was better when compared to $\mathrm{CgA}(93-98 \% \text { vs. } 50-80 \%)^{[33,54]}$ exceeding the performance criteria proposed by an expert panel convened to evaluate NET biomarkers. MAAAs and NETest in particular may improve diagnostic accuracy and offer better interdisciplinary perspective than single analyte testing.

\section{IS THERE A CLINICAL ROLE FOR NOVEL BIOMARKERS?}

Recently, several novel biomarkers for NETs have been developed using an integration of genomics and technology platforms. In addition to gene transcript by MAAAs, circulating tumor cell (CTC) and microRNA (miRNA) analyses have been proposed. ${ }^{[12]}$

Khan et al. ${ }^{[55]}$ showed that the number of CTC detected in patients with neuroendocrine tumors was comparable to other tumors in which CTC have been shown to have prognostic relevance. In this study, $47 \%$ of patients with midgut $(n=101)$ and $24 \%$ of patients with pancreatic $(n$ $=42$ ) tumors had $\geq$ two CTC detected. Presence of CTC was clearly associated with increasing tumor burden and weakly with tumor grade. In a more recent, large prospective study, the same group demonstrated that changes in CTC were associated with response to treatment and overall survival in metastatic neuroendocrine tumors, suggesting CTC may be useful as a surrogate marker to direct clinical decision making. ${ }^{[56]}$ Although there is an increasing interest in CTC as a biomarker, recent consensus concluded that CTC analyses have several technical limitations and need further validation before being adopted into routine clinical practice. ${ }^{[12]}$

There is also increasing interest in miRNAs as clinical biomarkers of tumorigenesis, treatment response and outcomes, but to date clinical data are scarce and clinical application challenging. Similarly, there are several novel monoanalyte assays (i.e. connective tissue growth factor for carcinoid heart disease (CCN2) or paraneoplastic Ma antigen 2 (PNMA2) for small intestinal neuroendocrine tumors, but these analyses are not available in clinical practice. ${ }^{[12]}$ Further, panelists of the recent Delphi consensus gave the strongest support to the use of emerging biomarkers in multianalyte technology based on genomics. ${ }^{[12]}$

\section{CONCLUSION}

To date, the identification of sensitive, specific and reproducible NET circulating biomarkers for the prediction, diagnosis, prognosis and classification of NETs and to evaluate changes during therapy has been limited $^{[12]}$ and remains an unfulfilled unmet medical need as defined by the 2007 National Cancer Institute NET meeting. ${ }^{[57]}$ There are no specific circulating monoanalyte biomarkers for neuroendocrine tumors that fulfill the $\mathrm{NIH}$ recommended criteria and the search continues for 
markers with diagnostic and prognostic capabilities. Since Feyrter have discovered the neuroendocrine equivalent of Pandora's Box, a unique relationship between these various neuroendocrine peptides and different tumors has not been found yet. ${ }^{[7]}$ We are hopeful that in the era of Precision Medicine, specific circulating markers or a multianalyte panel for specific tumor types can be developed for NETs giving more reliable diagnostic and prognostic information. The road is long and new, robust prospective studies in different neuroendocrine tumors settings are required before new accurate biomarkers are validated and implemented into routine clinical practice.

\section{Financial support and sponsorship}

Nil.

\section{Conflicts of interest}

There are no conflicts of interest.

\section{Patient consent}

No patient involved.

\section{Ethics approval}

This article does not contain any studies with human participants or animals.

\section{REFERENCES}

1. Yao JC, Hassan M, Phan A, Dagohoy C, Leary C, Mares JE, Abdalla EK, Fleming JB, Vauthey JN, Rashid A, Evans DB. One hundred years after "carcinoid": epidemiology of and prognostic factors for neuroendocrine tumors in 35,825 cases in the United States. $J$ Clin Oncol 26:3063-72.

2. Vinik AI, Silva MP, Woltering G, W.Go VL, Warner R, Caplin M. Biochemical Testing for Neuroendocrine Tumors. Pancreas 2009;38:876-89.

3. Vinik AI, Gonzales MR. New and emerging syndromes due to neuroendocrine tumors. Endocrinol Metab Clin North Am 2011;40:19-63

4. Metz DC, Choi J, Strosberg J, Heaney AP, Howden CW, Klimstra D, Yao JC. A rationale for multidisciplinary care in treating neuroendocrine tumours. Curr Opin Endocrinol Diabetes Obes 2012;19:306-13

5. Grimaldi F, Fazio N, Attanasio R, Frasoldati A, Papini E, Angelini F, Baldelli R, Berretti D, Bianchetti S, Bizzarri G, Caputo M, Castello R, Cremonini N, Crescenzi A, Davı MV, D'Elia AV, Faggiano A, Pizzolitto S, Versari A, Zini M, Rindi G, Oberg K. Italian Association of Clinical Endocrinologists (AME) position statement: a stepwise clinical approach to the diagnosis of gastroenteropancreatic neuroendocrine neoplasms. J Endocrinol Invest 2014;37:875-909.

6. Vinik AI, Chaya C. Clinical presentation and diagnosis of neuroendocrine tumors. Hematol Oncol Clin N Am 2016;30:21-48.

7. Modlin IM, Champaneria MC, Bornschein J, Kidd M. Evolution of the Diffuse Neuroendocrine System - Clear Cells and Cloudy Origins. Neuroendocrinology 2006;84:69-82.

8. Oberg K. Circulating biomarkers in gastroenteropancreatic neuroendocrine tumours. Endocr Relat Cancer 2011;18 Suppl 1:S17-25.

9. Kanakis G, Kaltsas G. Biochemical markers for gastroenteropancreatic neuroendocrine tumours (GEP-NETs). Best Pract Res Clin Gastroenterol 2012;26:791-802.

10. Bosman FT, Carneiro F. World Health Organization Classification of Tumours, Pathology and Genetics of Tumours of the Digestive System. Lyon: IARC Press 2010.

11. Kloppel G, Couvelard A, Perren A, Komminoth P, McNicol AM, Nilsson O, Scarpa A, Scoazec JY, Wiedenmann B, Papotti M, Rindi G, Plockinger U, and all other Mallorca Consensus Conference participants. ENETS Consensus Guidelines for the Standards of Care in Neuroendocrine Tumors: Towards a Standardized Approach to the Diagnosis of Gastroenteropancreatic Neuroendocrine Tumors and Their Prognostic Stratification. Neuroendocrinology 2009:90;162-6

12. Oberg K, Modlin IM, De Herder W, Pavel M, Klimstra D, Frilling A, Metz DC, Heaney A, Kwekkeboom D, Strosberg J, Meyer T, Moss SF, Washington K, Wolin E, Liu E, Gol-denring J. Consensus on biomarkers for neuroendocrine tumour disease. Lancet Oncol 2015;16:435-46.

13. Lawrence B, Gustafsson BI, Kidd M, Pavel M, Svejda B, Modlin IM. The clinical relevance of chromogranin $\mathrm{A}$ as a biomarker for gastroenteropancreatic neuroendocrine tumors. Endocrinol Metab Clin North Am 2011;40:111-34.

14. Modlin IM, Gustafsson BI, Moss SF, Pavel M, Tsolakis AV, Kidd M. Chromogranin A-biological function and clinical utility in neuro endocrine tumor disease. Ann Surg Oncol 2010;17:2427-43.

15. Giusti M, Sidoti M, Augeri C, Rabitti C, Minuto F. Effect of shortterm treatment with low dosages of the proton-pump inhibitor omeprazole on serum chromogranin A levels in man. Eur $J$ Endocrinol 2004;150:299-303.

16. Yang X, Yang Y, Li Z, Cheng C, Yang T, Wang C, Liu L, Liu S. Diagnostic value of circulating chromogranin a for neuroendocrine tumors: a systematic review and meta-analysis. PLoS One 2015;10:e124884.

17. Zatelli MC, Torta M, Leon A, Ambrosio MR, Gion M, Tomassetti P, De Braud F, Delle Fave G, Dogliotti L, degli Uberti EC; Italian CromaNet Working Group. Chromogranin A as a marker of neuroendocrine neoplasia: an Italian Multicenter Study. Endocr Relat Cancer 2007:14:473-82.

18. Bajetta E, Ferrari L, Martinetti A, Celio L, Procopio G, Artale S, Zilembo N, Di Bartolomeo M, Seregni E, Bombardieri E. Chromogranin A, neuron specific enolase, carcinoembryonic antigen, and hydroxyindole acetic acid evaluation in patients with neuroendocrine tumors. Cancer 1999;86:858-65.

19. Janson ET, Holmberg L, Stridsberg M, Eriksson B, Theodorsson E, Wilander E, Oberg K. Carcinoid tumors: analysis of prognostic factors and survival in 301 patients from a referral center. Ann Oncol 1997;8:685-90

20. Sherman SK, Maxwell JE, O'Dorisio MS, O'Dorisio TM, Howe JR. Pancreastatin predicts survival in neuroendocrine tumors. Ann Surg Oncol 2014;21:2971-80.

21. Frank R, Hargreaves R. Clinical biomarkers in drug discovery and development. Nat Rev Drug Discov 2003;2:566-80.

22. Jensen RT, Cadiot G, Brandi ML, de Herder WW, Kaltsas G, Komminoth P, Scoazec JY, Salazar R, Sauvanet A, Kianmanesh R; Barcelona Consensus Conference participants. ENETS Consensus Guidelines for the Management of Patient with Digestive Neuroendocrine Neoplasms: Functional Pancreatic Endocrine Tumor Syndromes. Neuroendocrinology 2012;95:98-119

23. Cryer PE, Axelrod L, Grossman AB, Heller SR, Montori VM, Seaquist ER, Service FJ; Endocrine Society. Evaluation and management of adult hypoglycemic disorders: an Endocrine Society Clinical Practice Guideline. J Clin Endocrinol Metab 2009;94:709-28.

24. Kon T, Wada R, Suzuki R, Nakayama Y, Ebina Y, Yagihashi S. VIP and calcitonin-producing pancreatic neuroendocrine tumor with watery diarrhea: clinicopathological features and the effect of somatostatin analogue. JOP 2012;13:226-30.

25. Falconi M, Eriksson B, Kaltsas G, Bartsch DK, Capdevila J, Caplin M, Kos-Kudla B, Kwekkeboom D, Rindi G, Klöppel G, Reed N, Kianmanesh R, Jensen RT; all other Vienna Consensus Conference participants. Consensus Guidelines Update for the Management of Functional p-NETs (F-p-NETs) and Non-Functional p-NETs (NF-pNETs). Neuroendocrinology 2016;103:153-71.

26. Boscaro M. Arnaldi G. Approach to the Patient with Possible Cushing's Syndrome. J Clin Endocrinol Metab 2009;94:3121-31.

27. Grohé C Berardi R, Burst V. Hyponatraemia-SIADH in lung cancer diagnostic and treatment algorithms. Crit Rev Oncol Hematol 2015;96:1-8.

28. Barakat MT, Meeran K, Bloom SR. Neuroendocrine tumours. Endocr Relat Cancer 2004;11:1-18.

29. Kunz PL, Reidy-Lagunes D, Anthony LB, Bertino EM, Brendtro K, Chan JA, Chen H, Jensen RT, Kim MK, Klimstra DS, Kulke MH, 
Liu EH, Metz DC, Phan AT,Sippel RS, Strosberg JR, Yao JC; North American Neuroendocrine Tumor Society. Consensus guidelines for the management and treatment of neuroendocrine tumors. Pancreas 2013;42:557-77.

30. Jilesen AP, Busch OR, van Gulik TM, Gouma DJ, Nieveen van Dijkum EJ. Standard pre- and postoperative determination of chromogranin a in resectable non-functioning pancreatic neuroendocrine tumors--diagnostic accuracy: NF-pNET and low tumor burden. Dig Surg 2014;31:407-14.

31. O'Toole D, Grossman A, Gross D, Delle Fave G, Barkmanova J, O'Connor J, Pape UF, Plöckingerg U and all other Mallorca Consensus Conference participants. ENETS Consensus Guidelines for the Standards of Care in Neuroendocrine Tumors: Biochemical Markers. Neuroendocrinology 2009;90:194-202.

32. Kulke MH, Shah MH, Benson AB 3rd, Bergsland E, Berlin JD, Blaszkowsky LS, Emerson L, Engstrom PF, Fanta P, Giordano T, Goldner WS, Halfdanarson TR, Heslin MJ, Kan-deel F, Kunz PL, Kuvshinoff BW 2nd, Lieu C, Moley JF, Munene G, Pillarisetty VG, Saltz L, Sosa JA, Strosberg JR, Vauthey JN, Wolfgang C, Yao JC, Burns J, Freedman-Cass D; National comprehensive cancer network. Neuroendocrine tumors, version 1.2015. J Natl Compr Canc Netw 2015;13:78-108.

33. Ramage JK, Ahmed A, Ardill J, Bax N, Breen DJ, Caplin ME, Corrie P, Davar J, Davies AH, Lewington V, Meyer T, NewellPrice J, Poston G, Reed N, Rockall A, Steward W, Thakker RV, Toubanakis C, Valle J, Verbeke C, Grossman AB. Guidelines for the management of gastroenteropancreatic neuroendocrine (including carcinoid) tumours (NETs). Gut 2012;61:6-32.

34. Yao JC, Pavel M, Phan AT, Kulke MH, Hoosen S, St. Peter J, Cherfi A, Öberg KE. Chromogranin A and neuron-specific enolase as prognostic markers in patients with advanced pNET treated with everolimus. J Clin Endocrinol Metab 2011;96:3741-9.

35. van Adrichem RC, Kamp K, Vandamme T, Peeters M, Feelders RA, de Herder WW. Serum neuron-specific enolase level is an independent predictor of overall survival in patients with gastroenteropancreatic neuroendocrine tumors. Ann Oncol 2015; 27:746-7.

36. Kulke MH, Siu LL, Tepper JE, Fisher G, Jaffe D, Haller DG, Ellis LM, Benedetti JK, Bergsland EK, Hobday TJ, Van Cutsem E, Pingpank J, Oberg K, Cohen SJ, Posner MC, Yao JC. Future directions in the treatment of neuroendocrine tumors: consensus report of the National Cancer Institute Neuroendocrine Tumor Clinical Trials Planning Meeting. J Clin Oncol 2011;29:934-43.

37. Vinik AI, Woltering EA, Warner RP, Caplin M, O'Dorisio TM, Wiseman GA, Coppola D, Go WLW. NANETS consensus guidelines for the diagnosis of neuroendocrine tumor. Pancreas 2010;39:713-34

38. Phan AT, Oberg K, Choi J, Harrison LH Jr, Hassan MM, Strosberg JR, Krenning EP, Ko-cha W, Woltering EA, Maples WJ. NANETS consensus guideline for the diagnosis and management of neuroendocrine tumors: well-differentiated neuroendocrine tumors of the thorax (includes lung and thymus). Pancreas 2010;39:784-98

39. Boudreaux JP, Klimstra DS, Hassan MM, Woltering EA, Jensen RT, Goldsmith SJ, Nutting CDO, Bushnell DL, Caplin ME, Yao JC. The NANETS Consensus Guideline for the diagnosis and management of neuroendocrine tumors: well-differentiated neuroendocrine tumors of the Jejunum, Ileum, Appendix, and Cecum. Pancreas 2010;39:753-66.

40. Kulke MH, Anthony LB, Bushnell DL, de Herder WW, Goldsmith SJ, Klimstra DS, Marx SJ, Pasieka JL, Pommier RF, Yao JC, Jensen RT. NANETS treatment guidelines: well-differentiated neuroendocrine tumors of the stomach and pancreas. Pancreas 2010;39:735-52

41. Öberg K, Knigge U, Kwekkeboom D, Perren A on behalf of the ESMO Guidelines Working Group. Neuroendocrine gastroentero-pancreatic tumors: ESMO Clinical Practice Guidelines for diagnosis, treatment and follow-up. Annals Oncol 2012;23:124-30.

42. Öberg K, Hellman P, Ferolla P, Papotti M; ESMO Guidelines Working Group. Neuroendocrine bronchial and thymic tumors: ESMO Clinical Practice Guidelines for diagnosis, treatment and follow-up. Ann Oncol 2012;23:120-3.

43. Caplin ME, Baudin E, Ferolla P, Filosso P, Garcia-Yuste M, Lim E, Oberg K, Pelosi G, Perren A, Rossi RE, Travis WD; ENETS consensus conference participants. Pulmonary neuroendocrine (carcinoid) tumors: European Neuroendocrine Tumor Society expert consensus and recommendations for best practice for typical and atypical pulmonary carcinoids. Ann Oncol 2015;26:1604-20.

44. Niederle B, Pape UF, Costa F, Gross D, Kelestimur F, Knigge U, Öberg K, Pavel M, Perren A, Toumpanakis C, O’Connor J, O'Toole D, Krenning E, Reed N, Kianmanesh R; all other Vienna Consensus Conference participants. ENETS Consensus Guidelines Update for Neuroendocrine Neoplasm of the Jejunum and Ileum. Neuroendocrinology 2016;103:125-38.

45. Frilling A, Modlin IM, Kidd M, Russell C, Breitenstein S, Salem R, Kwekkeboom D, Lau WY, Klersy C, Vilgrain V, Davidson B, Siegler M, Caplin M, Solcia E, Schilsky R; Working Group on Neuroendocrine Liver Metastases. Recommendations for management of patients with neuroendocrine liver metastases. Lancet Oncol 2014;15:8-21.

46. Berna MJ, Hoffmann KM, Serrano J, Gibril F, Jensen RT. Serum gastrin in Zollinger-Ellison syndrome: I. Prospective study of fasting serum gastrin in 309 patients from the National Institutes of Health and comparison with 2229 cases from the literature. Medicine (Baltimore) 2006;85:295-330.

47. Massironi S, Conte D, Sciola V, Spampatti MP, Ciafardini C, Valenti L, Rossi RE, Peracchi M. Plasma chromogranin A response to octreotide test: prognostic value for clinical outcome in endocrine digestive tumors. Am J Gastroenterol 2010;105:2072-8.

48. Massironi S, Rossi RE, Casazza G, Conte D, Ciafardini C, Galeazzi $\mathrm{M}$, Peracchi M. Chromogranin A in diagnosing and monitoring patients with gastroenteropancreatic neuroendocrine neoplasms: a large series from a single institution. Neuroendocrinology 2014;100:240-9.

49. Rossi RE, Garcia-Hernandez J, Meyer T, Thirlwell C, Watkins J, Guy Martin N, Caplin ME, Toumpanakis C. Chromogranin A as a predictor of radiological disease progression in neuroendocrine tumours. Ann Transl Med 2015;3:118.

50. Jensen EH, Kvols L, McLoughlin JM, Lewis JM, Alvarado MD, Yeatman T, Malafa M, Shibata D. Biomarkers predict outcomes following cytoreductive surgery for hepatic metastases from functional carcinoid tumors. Ann Surg Oncol 2007;14:780-5.

51. Kwekkeboom DJ, Teunissen JJ, Bakker WH, Kooij PP, de Herder WW, Feelders RA, van Eijck CH, Esser JP, Kam BL, Krenning EP. Radiolabeled somatostatin analog [177Lu-DOTA0, Tyr3]octreotate in patients with endocrine gastroenteropancreatic tumors. $J$ Clin Oncol 2005;23:2754-62.

52. Olausson M, Friman S, Herlenius G, Cahlin C, Nilsson $\mathrm{O}$, Jansson S, Wängberg $\mathrm{B}$, Ahl-man $\mathrm{H}$. Orthotopic liver or multivisceraltransplantation as treatment of metastatic neuroendocrine tumors. Liver Transpl 2007;13:327-33.

53. Modlin IM, Drozdov I, Alaimo D, Callahan S, Teixiera N, Bode L, Kidd M. A multianalyte PCR blood test outperforms single analyte ELISAs (chromogranin A, pancreastatin, neurokinin A) for neuroendocrine tumor detection. Endocr Relat Cancer 2014;21:615-28.

54. Modlin IM, Aslanian H, Bodei L, Drozdov I, Kidd M. A PCR blood test outperforms chromogranin A in carcinoid detection and is unaffected by proton pump inhibitors. Endocr Connect 2014;3:215-23.

55. Khan MS, Kirkwood A, Tsigani T, Garcia-Hernandez J, Hartley JA, Caplin ME, Meyer T. Circulating tumor cells as prognostic markers in neuroendocrine tumors. J Clin Oncol 2013;31:365-72.

56. Khan MS, Kirkwood AA, Tsigani T, Lowe H, Goldstein R, Hartley JA, Caplin ME, Meyer T. Early changes in circulating tumor cells are associated with response and survival following treatment of metastatic neuroendocrine neoplasms. Clin Cancer Res 2016;22:79-85.

57. Modlin IM, Moss SF, Chung DC, Jensen RT, Snyderwine E. Priorities for improving the management of gastroenteropancreatic neuroendocrine tumors. J Natl Cancer Inst 2008;100:1282-9. 